\title{
Combined SAGE II-GOMOS ozone profile data set for 1984-2011 and trend analysis of the vertical distribution of ozone
}

\author{
E. Kyrölä ${ }^{1}$, M. Laine ${ }^{1}$, V. Sofieva ${ }^{1}$, J. Tamminen ${ }^{1}$, S.-M. Päivärinta ${ }^{1}$, S. Tukiainen ${ }^{1}$, J. Zawodny ${ }^{2}$, and L. Thomason ${ }^{2}$ \\ ${ }^{1}$ Finnish Meteorological Institute, Earth Observation Unit, P.O. Box 503, 00101 Helsinki, Finland \\ ${ }^{2}$ NASA Langley Research Center, MS-475, Hampton, VA 23681-2199, USA
}

Correspondence to: E. Kyrölä (erkki.kyrola@fmi.fi)

Received: 15 February 2013 - Published in Atmos. Chem. Phys. Discuss.: 23 April 2013

Revised: 12 September 2013 - Accepted: 1 October 2013 - Published: 4 November 2013

\begin{abstract}
We have studied data from two satellite occultation instruments in order to generate a high vertical resolution homogeneous ozone time series of $26 \mathrm{yr}$. The Stratospheric Aerosol and Gas Experiment (SAGE) II solar occultation instrument and the Global Ozone Monitoring by Occultation of Stars (GOMOS) instrument measured ozone profiles in the stratosphere and mesosphere from 1984-2005 and 2002-2012, respectively. Global coverage, good vertical resolution, and the self-calibrating measurement method make data from these instruments valuable for the detection of changes in vertical distribution of ozone over time. As both instruments share a common measurement period from 2002-2005, it is possible to inter-calibrate the data sets. We investigate how well these measurements agree with each other and combine all the data to produce a new stratospheric ozone profile data set. Above $55 \mathrm{~km}$, SAGE II measurements show much less ozone than the GOMOS nighttime measurements as a consequence of the well-known diurnal variation of ozone in the mesosphere. Between $35-55 \mathrm{~km}$, SAGE II sunrise and sunset measurements differ from GOMOS' measurements to different extents. Sunrise measurements show $2 \%$ less ozone than GOMOS, whereas sunset measurements show $4 \%$ more ozone than GOMOS. Differences can be explained qualitatively by the diurnal variation of ozone in the stratosphere recently observed by SMILES and modeled by chemical transport models. Between $25-35 \mathrm{~km}$, SAGE II sunrise and sunset measurements and GOMOS measurements agree within $1 \%$.

The observed ozone bias between collocated measurements of SAGE II sunrise/sunset and GOMOS night measurements is used to align the two data sets. The combined data set covers the time period 1984-2011, latitudes $60^{\circ} \mathrm{S}-$ $60^{\circ} \mathrm{N}$, and the altitude range of $20-60 \mathrm{~km}$. Profile data are
\end{abstract}

given on a $1 \mathrm{~km}$ vertical grid, and with a resolution of 1 month in time and $10^{\circ}$ in latitude. The combined ozone data set is analyzed by fitting a time series model to the data. We assume a linear trend with an inflection point (so-called "hockey stick" form). The best estimate for the point of inflection was found to be the year 1997 for ozone between altitudes 35 and $45 \mathrm{~km}$. At all latitudes and altitudes from 35 to $50 \mathrm{~km}$ we find a clear change in ozone trend before and after the inflection time. From 38 to $45 \mathrm{~km}$, a negative trend of $4 \%$ per decade (statistically significant at $95 \%$ level) at the equator has changed to a small positive trend of $0-2 \%$ per decade. At mid-latitudes, the negative trend of $4-8 \%$ per decade has changed to to a small positive trend of $0-2 \%$ per decade. At mid-latitudes near $20 \mathrm{~km}$, the ozone loss has still increased whereas in the tropics a recovery is ongoing.

\section{Introduction}

The stratospheric ozone decline, especially the drastic decrease of ozone over the Antarctic, has been a focus of middle atmosphere research during the past $25 \mathrm{yr}$ (for reviews, see Solomon, 1999; Staehelin et al., 2001; WMO, 2011). An understanding of the causes of ozone loss was quickly established after the ozone hole discovery, and an international agreement about the control of ozone-depleting substances was reached in Montreal in 1987. These controls have led to a decline of atmospheric chlorine and bromine - the most important substances in ozone loss - in the stratosphere since 1997. An improved understanding of the ozone loss problem along with the advances in the middle atmosphere modeling have made it possible to predict a complete recovery of 
stratospheric ozone between 2050 and 2070 (for a review of ozone depletion science, see WMO, 2011).

In order to follow the development of middle atmosphere ozone, global measurements are needed. Ground-based instruments and ozone sondes can monitor ozone mainly in the lower stratosphere, but in order to attain a global view of trends, satellite instruments need to be used. There are excellent long time series of the total ozone and its evolution, but in order to investigate the details of the processes involved, vertical ozone profiles are required. Several studies have used satellite measurements to study the decline of ozone and ozone's predicted recovery (see e.g., Harris et al., 1999; Weatherhead et al., 2000; Newchurch et al., 2003; Steinbrecht et al., 2006, 2009; Randel and Wu, 2007; Jones et al., 2009). Weak signs of the ozone recovery have already been detected in studies by Newchurch et al. (2003), Steinbrecht et al. (2009), and Jones et al. (2009).

Past changes in the average ozone levels have taken place slowly, and this pace is predicted to continue. Therefore, requirements for the stability of ozone observations are stringent. The stability means that a given ozone density in the atmosphere produces the same retrieved ozone value (allowing variation by noise) independent of the measurement time. Instrumental factors or changes in retrieval parameters are obvious sources for affecting the stability. From the instrumental point of view, self-calibrating occultation instruments are good candidates for long-term monitoring of ozone. The SAGE II instrument (Chu et al., 1989) made 168075 solar occultation measurements of ozone in the stratosphere and lower mesosphere from 1984 to 2005 . The more recent Global Ozone Monitoring by Occultation of Stars (GOMOS) instrument (Bertaux et al., 2010) measured ozone in the stratosphere, mesosphere and lower thermosphere from 2002-2012 using stellar occultations. There are more than 877000 GOMOS measurements covering both day and night. In this work, we use the GOMOS 410000 night measurements.

In this paper, we combine the ozone data sets from SAGE II and GOMOS to create a homogeneous time series from 1984 to 2011 in order to look for changes in the middle atmospheric ozone profiles. We first introduce the instruments and the retrieval methods, and the applied data filtering in Sects. 2-4. The differences between the SAGE II and GOMOS ozone profiles are studied in Sect. 5 using collocated measurements in the 2002-2005 shared operation period of the two instruments. The observed bias in ozone profiles is eliminated and the two data sets are combined in Sect. 6. In Sect. 7, we introduce a time-dependent model including a linear term, annual and semiannual terms as well as proxies for the solar influence and the quasi-biennial oscillation (QBO). The linear term of the model fitted is used to derive ozone trends in Sect. 8.

\section{SAGE II and GOMOS measurements}

SAGE II was launched in 1984 on board the Earth Radiation Budget Satellite (ERBS). The SAGE II predecessor is the SAGE I solar occultation instrument (McCormick et al., 1989), which was operational from 1979-1981. Both rising and setting solar occultations were observed by SAGE II. Ozone profiles are given on a regular grid from $0.5 \mathrm{~km}$ to $70 \mathrm{~km}$ with a step of $0.5 \mathrm{~km}$. In $21 \mathrm{yr}$, (1984-2005) SAGE II measured 168075 solar occultations. In Fig. 1, we show how the measurements are distributed over the years. The number of measurements is stable from 1985-1999 (with the exception of 1993, when a battery problem decreased the number of successful measurements), but decreases towards the end of the mission. The number of measurements from sunrises and sunsets is nearly equal throughout the mission. In Fig. 2, we show the latitudinal distribution of measurements from SAGE II in 1985 and 2004. The latitude distribution peaks at $50^{\circ}$ and has a minimum at the equator. Sunrise and sunset measurement are similarly distributed in the beginning of the SAGE II mission, but the distributions differ towards the end of the mission.

SAGE II has seven wavelength channels centered at 386, $448,452,525,600,940$, and $1020 \mathrm{~nm}$. The $\mathrm{O}_{3}$ and $\mathrm{NO}_{2}$ density and the aerosol extinction profiles at each wavelength are retrieved using data from five wavelength channels, 448, 452, 525,600 , and $1020 \mathrm{~nm}$. The aerosol extinction at 448 and $600 \mathrm{~nm}$ is approximated by a linear interpolation from 452 , 525 and $1020 \mathrm{~nm}$ aerosols assuming the aerosol extinction coefficient spectra are consistent with those produced by lognormal aerosol size distributions (for details, see Damadeo et al., 2013).

The original SAGE II algorithm was presented in Chu et al. (1989). Subsequent improvements and validations have been discussed in several publications (e.g., Cunnold et al., 1989; Wang et al., 1992; McPeters et al., 1994; Wang et al., 1996; Steele and Turco, 1997; Cunnold et al., 2000; Wang, 2002; Burton et al., 2010). The data version used in this work is 7.0, which was issued in November 2012. The main differences with respect to the earlier version, 6.2, are: (1) the ozone cross section is now the same as for GOMOS (Bogumil et al., 2003), (2) the background atmospheric data now come from the Modern-Era Retrospective Analysis for Research and Applications (MERRA, Rienecker et al., 2011), and (3) the vertical inversion is performed using the onionpeeling technique without any smoothing. The ozone values in the new version have decreased by $1-2 \%$ with respect to those in the earlier version, mainly because of the change in the ozone cross section. The validation work for the new SAGE II data set is underway (see Damadeo et al., 2013).

GOMOS was a stellar occultation instrument on board the European Environmental Satellite (ENVISAT) that was operational from 2002 to 2012 (for GOMOS overviews, see Bertaux et al., 2010; ESA, 2001, and https://earth.esa.int/web/guest/missions/ 

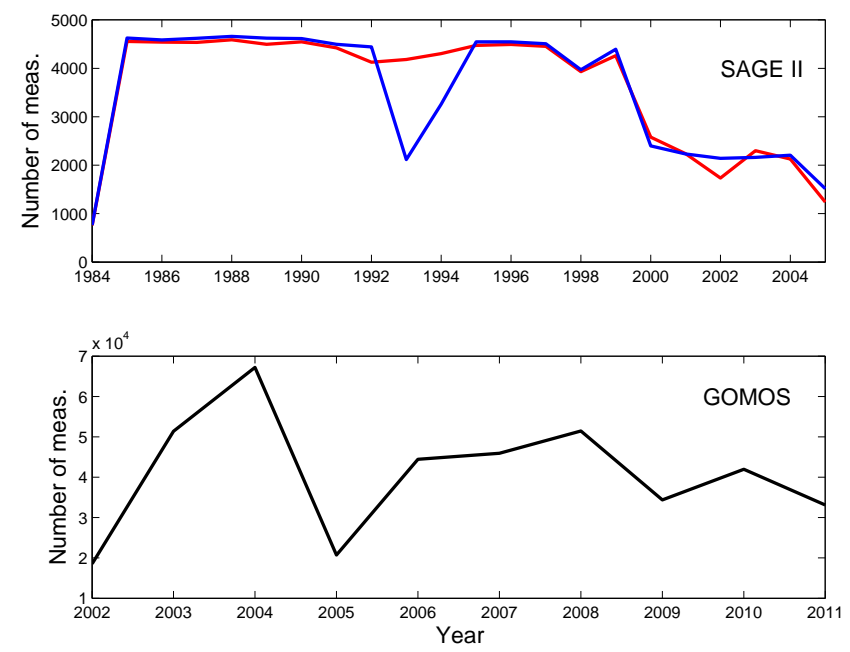

Fig. 1. The number of SAGE II sunrise (red) /sunset (blue) measurements for 1984-2005 and GOMOS nighttime measurements (black) for 2002-2011.

esa-operational-eo-missions/envisat/instruments/gomos). GOMOS measured during both day and night, but only nighttime measurements have been validated so far. The integration time is $0.5 \mathrm{~s}$, which gives an altitude sampling resolution of $0.2-1.6 \mathrm{~km}$ depending on the tangent altitude and the azimuth angle of the measurement. The total number of nighttime measurements is 409 157. In Fig. 1, we show how the measurements are distributed over the years, and in Fig. 2, we show the latitudinal distribution of measurements in 2004 and 2010. The number of measurements peaked in 2004 and declined thereafter, due to an instrument problem that strongly decreased the number of measurements in 2005. The latitudinal distribution is more even than for SAGE II because GOMOS has approximately 100 different target stars in various directions, whereas SAGE II has only one target, the sun.

The spectral ranges of GOMOS detectors are $248-690 \mathrm{~nm}$, 755-774 nm, and 926-954 nm, making it possible to retrieve vertical profiles of $\mathrm{O}_{3}, \mathrm{NO}_{2}, \mathrm{NO}_{3}, \mathrm{H}_{2} \mathrm{O}, \mathrm{O}_{2}$, and aerosols. In this work, we concentrate on ozone that is retrieved from the UV-visible spectral range 248-690 nm together with $\mathrm{NO}_{2}$, $\mathrm{NO}_{3}$, and aerosols. The retrieved ozone profiles have a $2 \mathrm{~km}$ vertical resolution below $30 \mathrm{~km}$ and a $3 \mathrm{~km}$ resolution above $40 \mathrm{~km}$, whereas $\mathrm{NO}_{2}$ and $\mathrm{NO}_{3}$ have a $3 \mathrm{~km}$ vertical resolution at all altitudes. Details of the GOMOS retrieval algorithms and data quality are discussed in Kyrölä et al. (2010b) and Tamminen et al. (2010).

The geophysical validation of measurements with different illumination conditions is presented in Meijer et al. (2004), and, more recently, in van Gijsel et al. (2010). Results show that in the dark limb GOMOS ozone profile data for between $20-40 \mathrm{~km}$ agree within a few percent with the correlative data at all latitudes excluding the polar areas.
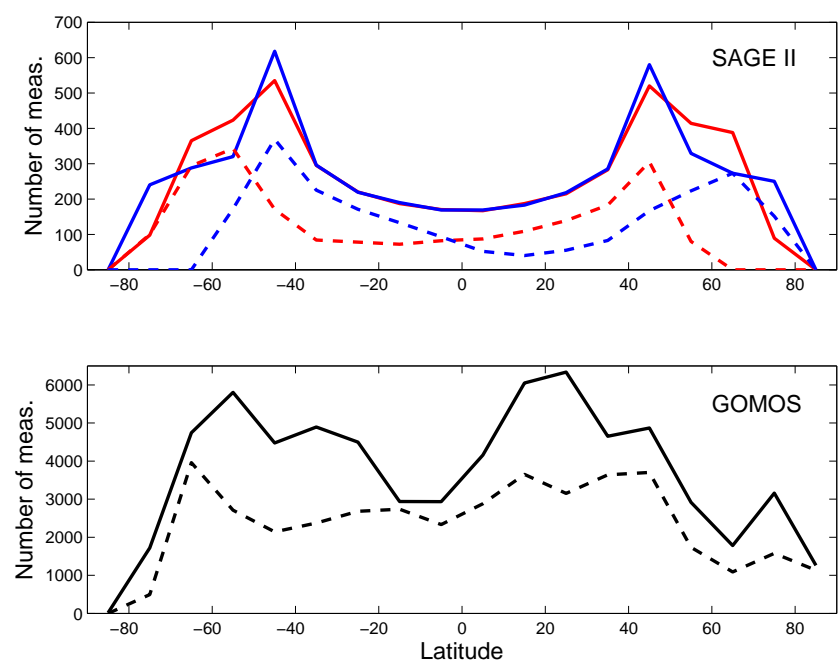

Fig. 2. Latitude distributions of SAGE II (top) and GOMOS (bottom) measurements. Notation: Solid and dashed red: SAGE II sunrise for 1985 and 2004, solid and dashed blue: SAGE II sunset for 1985 and 2004, solid and dashed black: GOMOS for 2004 and 2010.

In this work, we use GOMOS data from the Instrument Processor Facility (IPF) version 6, issued in November 2012. Its main differences with respect to the IPF version 5 are the use of a full covariance matrix in the spectral inversion that has made the error estimates of ozone more realistic, and more accurate dark current removal that has improved the stability of the data products. The validation of the new version is underway.

\section{Retrievals compared}

The measurements and retrievals of these two instruments are similar but not identical (see Table 1). The Sun is an extended source of radiation whereas stars appear as point sources to satellite instruments. Rays from both radiation sources are bent by refraction where chromatic dispersion must also be taken into account. The radiation field from stars enters the atmosphere as a parallel ray bundle and is sensitive to local fluctuations in temperature and to the overall altitude dependence of the neutral density. The parallelism of rays is distorted, causing dilution of the radiation intensity. Rays are also affected by fluctuations leading to scintillations. These two effects are not seen in solar occultation measurements. The dilution effect can be eliminated using ray optics modeling and an a priori model for the neutral density. The scintillation effect can be partially eliminated by using GOMOS fast photometers (see Sofieva et al., 2010).

GOMOS measures at 1416 wavelengths in the UV-visible range and SAGE II at seven wavelengths, from the visible to the near infrared. The same constituents can be retrieved from these measurements. In both retrievals the Rayleigh 
Table 1. SAGE II and GOMOS (UV-Vis) retrieval compared.

\begin{tabular}{lll}
\hline Element & GOMOS IPF 6 & SAGE II v. 7 \\
\hline Refraction & Ray bending, dilution, scintillations & Ray bending \\
\hline Forward model & $\begin{array}{l}\text { Absorption by } \mathrm{O}_{3}, \mathrm{NO}_{2}, \mathrm{NO}_{3} ; \text { scatter- } \\
\text { ing ext. by air and aerosols }\end{array}$ & $\begin{array}{l}\text { Absorption by } \mathrm{O}_{3}, \mathrm{NO}_{2} ; \text { scattering ext. } \\
\text { by air and aerosols }\end{array}$ \\
\hline Wavelengths & $250-680 \mathrm{~nm}, 1416$ pixels & $\begin{array}{l}386,448, \text { 452, 525, 600, 940 and } \\
1020 \mathrm{~nm}\end{array}$ \\
\hline Rayleigh extinction & Removed using ECMWF & Removed using MERRA \\
\hline Species separation & Simultaneously & Simultaneously \\
\hline Aerosol model & Second order polynomial in wavelength & Mie theory \\
\hline Vertical inversion & Onion peeling with target resolution & Onion peeling without smoothing \\
& $\begin{array}{l}\text { Tikhonov and the constraint of density } \\
\text { continuity. }\end{array}$ & \\
\hline Ozone cross section & Bogumil et al. (2003) & Bogumil et al. (2003) \\
\hline Local time & Near 10 p.m. outside polar areas & Sunrise and sunset \\
\hline Vertical sampling & $0.2-1.7 \mathrm{~km}$ & Scanning \\
\hline Vertical resolution & 2 km (up to 30 km); 3 km above 40 km & 1 km \\
\hline Reference & Kyrölä et al. (2010b) & Damadeo et al. (2013) \\
\hline
\end{tabular}

extinction is first eliminated using either European Centre for Medium-Range Weather Forecasts (ECMWF) operational data (altitudes lower than $1 \mathrm{hPa}$ ) or MSIS90 climatology Hedin (1991) (higher than $1 \mathrm{hPa}$ ) in the case of GOMOS, and MERRA in the case of SAGE II. At the comparison altitudes these two neutral density data sets differ by $2-3 \%$ at most. The other constituents are retrieved simultaneously in GOMOS and SAGE II. In GOMOS, the aerosols are fitted using a second-order polynomial in wavelength, whereas SAGE II makes use of the Mie scattering theory. The SAGE II data version 7 uses the same ozone cross section (Bogumil et al., 2003) as GOMOS. In the vertical inversion, GOMOS uses the onion-peeling inversion along with the target resolution Tikhonov smoothing (Sofieva et al., 2004). SAGE II uses the standard onion-peeling technique without any smoothing.

The stability of the SAGE II and GOMOS instruments is the crucial underlying assumption when combining these data sets and using the combined data for ozone trend studies. The self-calibrating measurement principle reduces possible reasons for drifts of data products. The data retrieval is based on atmospheric (horizontal) transmissions where the measurements through the atmosphere are divided by the above the atmosphere measurement of the Sun (SAGE II) or a star (GOMOS). In the ideal case, this would lead to the cancelation of multiplicative calibration factors. In practice, instrumental noise (dark current) must first be removed from the measurements, which weakens the self-calibration. There are also other factors that are immune to the firewall of the self-calibration. For example, the retrievals of ozone include a priori data of atmospheric temperature and density whose accuracy may change with time. The estimation of the possible drifts in ozone measurements have been investigated using stable ground-based instruments. These studies indicate a $0.3 \% \mathrm{yr}^{-1}$ drift at most for SAGE II (see Nair et al., 2011, 2012). For GOMOS, Nair et al. (2011) reported somewhat larger values. However, due to the short measurement series, no conclusion can be made at this time. Furthermore, these studies have used the previous data versions of SAGE II and GOMOS. The data versions used in this work are currently being validated and studied for possible drifts.

\section{Data screening}

Both data sets are screened for erroneous ozone profiles. For SAGE II, data are screened using the error estimates as explained in the SAGE II version 7 readme file (https://eosweb.larc.nasa.gov/project/sage2/ sage2_release_v7_notes). Any profile with an error estimate larger than $10 \%$ between $30-50 \mathrm{~km}$ is rejected. All data below the tropopause height are rejected. Data at and below altitudes of $35 \mathrm{~km}$ where the error estimates are larger than $200 \%$ are eliminated. Data are also eliminated below the level where the $1020 \mathrm{~nm}$ aerosol extinction is larger than $0.001 \mathrm{~km}^{-1}$ and the aerosol extinction ratio $525 \mathrm{~nm} / 1020 \mathrm{~nm}$ is smaller than 1.4. The amount of data eliminated is about $5 \%$ of all SAGE II measurements between altitudes 20$60 \mathrm{~km}$. The final number of occultations used in this study 
is about $125000\left(60^{\circ} \mathrm{S}-60^{\circ} \mathrm{N}\right)$, including profiles with some flagged data points.

For GOMOS, we first eliminate measurements involving stars included in the GOMOS "cool and weak stars" list (see the GOMOS disclaimer, http://earth.eo.esa.int/pcs/envisat/gomos/documentation/ RMF_0117_GOM_NL_2P_Disclaimers.pdf). Any individual ozone profile is rejected if more than $40 \%$ of its points are flagged by the retrieval processor. Moreover, we reject all profiles in which the absolute value of the ozone mixing ratio exceeds $100 \mathrm{ppm}$ between $10 \mathrm{~km}$ and $110 \mathrm{~km}$, or in which the mixing ratios are outside the range $-0.5 \mathrm{ppm}$ to $20 \mathrm{ppm}$ from $15 \mathrm{~km}$ to $45 \mathrm{~km}$. The amount of data eliminated is about $3 \%$ of all GOMOS measurements (after the cool and weak star elimination) between 20 and $60 \mathrm{~km}$. The final number of profiles used in this study is about 215000 (in $\left.60^{\circ} \mathrm{S}-60^{\circ} \mathrm{N}\right)$.

\section{Comparison of SAGE II and GOMOS measurements from 2002-2005}

Both SAGE II and GOMOS took measurements during the period 2002 to 2005. During this time interval, SAGE II measured 12000 solar occultations (5800 sunrises and 6200 sunsets), and GOMOS measured 192000 quality-controlled stellar occultations during nighttime (solar zenith angle at true tangent point larger than $105^{\circ}$ ). The large number of measurements allows for a direct comparison between SAGE II and GOMOS ozone profiles. We use the following coincidence criteria (latitude $=\theta$, longitude $=\phi$, time $=t$ ):

$\Delta \theta<2^{\circ}, \Delta \phi<10^{\circ}, \Delta t<12 \mathrm{~h}$.

The method used to characterize the difference at each altitude, $z$, for a given profile is

$\Delta(z)=100 \frac{\left\langle f_{\mathrm{S}}(z)-f_{\mathrm{G}}(z)\right\rangle}{\left\langle f_{\mathrm{G}}(z)\right\rangle}$,

where $f_{\mathrm{S}}$ and $f_{\mathrm{G}}$ denote SAGE II and GOMOS vertical profiles in the altitude range $20-60 \mathrm{~km}$ with $1 \mathrm{~km}$ steps. The profiles are compared directly, without averaging kernels, as the vertical resolutions are comparable. The brackets denote the median over all the collocated measurements.

In Fig. 3, we show the difference between SAGE II- and GOMOS-collocated ozone profiles using the coincidence criteria defined above. We show SAGE II sunset and sunrise data separately because there is a clear difference between the values of these measurements. Above $55 \mathrm{~km}$ the difference between day and night ozone can be seen as a negative difference between SAGE II and GOMOS. For $35-55 \mathrm{~km}$, there is more ozone in SAGE II sunset measurements than in either GOMOS nighttime or SAGE II sunrise measurements. The overall mean SAGE II difference profile is biased towards sunset measurements, as the number of sunsets clearly

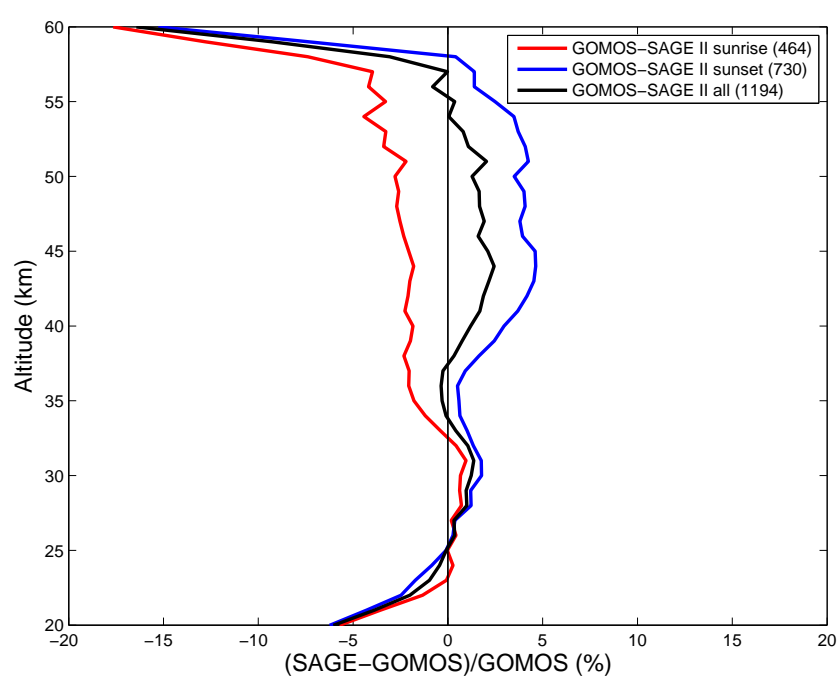

Fig. 3. The percent difference between SAGE II and GOMOS measurements for the collocations in 2002-2005. The corresponding differences between SAGE II sunrise and sunset measurements are also shown. The line labels show the number of collocations.

exceeds the number of sunrises. In the $25-35 \mathrm{~km}$ range, the differences between all the data sets are small. Below $25 \mathrm{~km}$ all the differences increase again, and are $5 \%$ at $20 \mathrm{~km}$.

The apparent difference between SAGE II and GOMOS ozone profiles can be attributed to various reasons. The deviations can arise from differences in instrumental behavior, retrieval techniques or real atmospheric conditions during the measurement period. There are no indications of relevant instrumental differences between SAGE II sunrise and sunset measurements even if we acknowledge the different radiation environments immediately before the actual measurements. We know, however, that the atmospheric transmission is different in nighttime, sunset, and sunrise measurements because $\mathrm{NO}_{2}$ has a strong diurnal variation. This was clearly seen when we compared GOMOS and SAGE II transmissions at collocation points. The $\mathrm{NO}_{2}$ content interferes with the ozone retrieval but this can be shown to be only of a minor contribution to the ozone values. Therefore, it is plausible that the observed differences between the GOMOS nighttime measurements and the SAGE II sunrise/sunset measurements reflect the real diurnal differences of the atmosphere.

The sunrise-sunset difference is inherent in the SAGE II data, and this can be visualized if we take SAGE II sunrise and sunset measurements in the tropics $\left(10^{\circ} \mathrm{S}-10^{\circ} \mathrm{N}\right)$. Tropical ozone values are relatively stable and the sunset-sunrise populations can be compared to each other with a good justification. The differences in $5 \mathrm{yr}$ periods are shown in Fig. 4. Between $35 \mathrm{~km}$ and $55 \mathrm{~km}$, the sunset profiles exhibit up to $10 \%$ more ozone than the sunrise profiles. The situation is reversed above $55 \mathrm{~km}$. Below $35 \mathrm{~km}$ there are no large differences except that, below $25 \mathrm{~km}$, the 2001-2005 period deviates strongly from the other periods. 


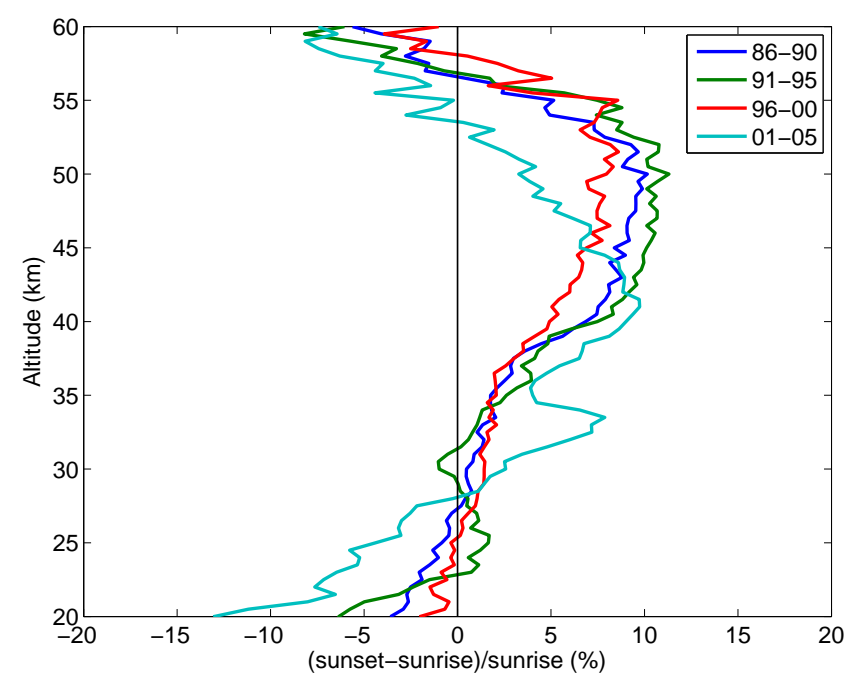

Fig. 4. The SAGE II ozone median of sunrise measurements compared to the median of sunset measurements for $5 \mathrm{yr}$ periods in the tropics $\left(10^{\circ} \mathrm{S}-10^{\circ} \mathrm{N}\right)$.

The observed large diurnal differences in ozone values at altitudes below $50 \mathrm{~km}$ (Figs. 3-4) are in contradiction with our understanding of ozone behavior in the stratosphere. Chemical box models predict very small variations in the stratosphere. The recent detailed measurements of the ozone diurnal cycle by the SMILES instrument and simulations by chemical-transport models show (see Sakazaki et al., 2013), however, a clear diurnal cycle of ozone in the stratosphere. SMILES results show that the magnitude between sunrise and sunset is about $4 \%(0.2 \mathrm{ppm})$, which is half of the variation of $8-10 \%(0.4 \mathrm{ppm})$ seen in Fig. 4. In Fig. 3, the SAGE II sunset-sunrise difference is about $6 \%$. It remains unknown as to why the differences inferred from SMILES are smaller than the ones observed by SAGE II and GOMOS. It must be noted that SMILES measurements cover only a limited period (from October 2009 to April 2010).

\section{Combined SAGE II - GOMOS data set}

In order to build a common data set from these two instruments, we need to find an optimal latitude-time grid for the combined data set and decide how to address the observed bias. We will also discuss what statistical estimators are appropriate for the problem. The data sets are limited to the latitude region $60^{\circ} \mathrm{S}-60^{\circ} \mathrm{N}$ in order to avoid seasonal gaps in the data. The extent in time covers years 1984-2011 (there are only a few GOMOS data from 2012 because of worsening GOMOS instrumental problems and finally because of the Envisat failure on 8 April 2012). The vertical grid is 20$60 \mathrm{~km}$ with a $1 \mathrm{~km}$ step.

\subsection{Common time-latitude grid}

We need to use a spatial and temporal grid where the measurements from both instruments are collected. Zonal averaging is a natural choice as the occultation instruments sample the longitudinal dimension regularly and with sufficient density. We define the filling factor for the time-latitude grid as the percentage (from all available cells) of those latitudetime cells where at least two measurements are found. A high grid filling value is a necessary prerequisite for the grid selection, and with a coarse grid this is always achieved. A desire to resolve natural variability would, on the other hand, demand more refined grids. The mean latitude-time average filling factors for several latitude-time grids are shown in Table 2 . In order to obtain a good coverage by both instruments, a monthly grid with 5-20 latitudinal bands can be selected. In the following we use $10^{\circ}$ latitude bands as a compromise between the latitudinal resolution and the filling degree.

The relatively large size of the time-latitude cells allows the natural variability of the ozone field to affect the representativity of the cell estimates. In order to quantify this, we define the latitudinal or temporal asymmetry of measurements in a grid cell as

$a_{S}=\frac{2\left\langle x-x_{\mathrm{c}}\right\rangle}{\Delta x}$.

This measures the mean location of the measurements $x$ with respect to the center of the cell centered at $x_{\mathrm{c}}$ and having width $\Delta x$. Figure 5 shows time series of asymmetries and ozone densities in the latitude band $50-60^{\circ} \mathrm{N}$. It is clear that large variability of asymmetries takes place for both instruments. In this case, there is a small SAGE II latitudinal asymmetry followed by a considerable positive asymmetry of GOMOS measurements. This may explain the change seen in the ozone densities at $40 \mathrm{~km}$ between SAGE II and GOMOS. In Fig. 6, we show the time averaged latitudinal and temporal asymmetries as a function of latitude. In the northernmost latitude band, the mean SAGE II latitude asymmetry is -0.13 and that for GOMOS is considerably larger (0.27). At other latitudes, the asymmetry differences between the two instruments are smaller and probably do not cause jumps in the time series of ozone density. The temporal asymmetry differences are smaller and we believe that they have a smaller impact on densities.

\subsection{Removal of bias}

It is clear that we cannot create a homogeneous data set from SAGE II and GOMOS without a proper consideration of the bias between these two data sets that was discussed in Sect. 5 . We have shown that the local time of the measurements has a strong influence on the bias. We still have to consider if the bias also depends on other parameters of the measurements, such as latitude and year. The small number of collocations makes these studies somewhat more uncertain than 
Table 2. SAGE II and GOMOS filling factors for various grids (\%).

\begin{tabular}{lll}
\hline Time $\times$ Latitude grid & SAGE II & GOMOS \\
\hline $1 \mathrm{~d} \times 5 \mathrm{deg}$ & 7 & 20 \\
$1 \mathrm{~d} \times 10 \mathrm{deg}$ & 12 & 34 \\
$1 \mathrm{~d} \times 20 \mathrm{deg}$ & 21 & 51 \\
$3 \mathrm{~d} \times 5 \mathrm{deg}$ & 14 & 26 \\
$3 \mathrm{~d} \times 10 \mathrm{deg}$ & 18 & 40 \\
$3 \mathrm{~d} \times 5 \mathrm{deg}$ & 27 & 50 \\
$5 \mathrm{~d} \times 5 \mathrm{deg}$ & 20 & 30 \\
$5 \mathrm{~d} \times 10 \mathrm{deg}$ & 24 & 44 \\
$5 \mathrm{~d} \times 20 \mathrm{deg}$ & 33 & 59 \\
1 Month $\times 5 \mathrm{deg}$ & 73 & 61 \\
1 Month $\times 10 \mathrm{deg}$ & 76 & 71 \\
1 Month $\times 20 \mathrm{deg}$ & 83 & 82 \\
\hline
\end{tabular}
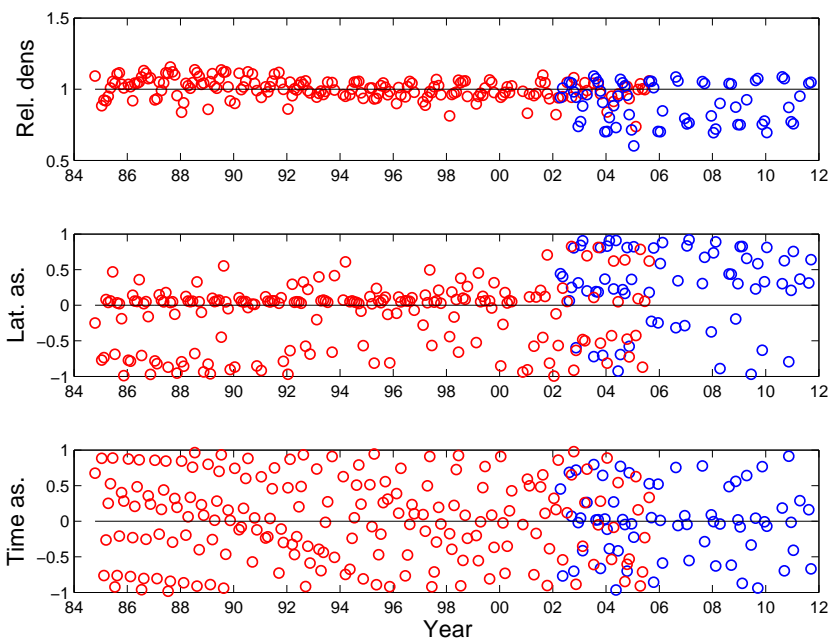

Fig. 5. Asymmetries of the monthly time series in the $50-60^{\circ} \mathrm{N}$ latitude range. Top: GOMOS and SAGE II ozone densities at $40 \mathrm{~km}$ scaled by the median of the combined time series at $40 \mathrm{~km}$, middle: latitude asymmetries, bottom: time asymmetries. Red circles are for SAGE II and blue circles for GOMOS data.

the plain sunset-sunrise comparisons. Figures 7 and 8 show the mean relative differences between SAGE II and GOMOS in 2002-2005 in different latitude belts. The differences from all latitudes are reasonably close to each other except in the southernmost latitude belt for sunset measurements. By comparing years and individual months, the culprit for this outlier is found to be the GOMOS-SAGE II sunset comparisons in June 2003 around $48^{\circ} \mathrm{S}$. The sunset-sunrise comparison for individual years is shown in Fig. 9. The bias patterns seem stable during 2002-2005.

The easiest solution to the bias problem would be to simply ignore any sunrise-sunset difference and correct the remaining bias from either GOMOS or SAGE II data. This would, however, require a near complete similarity between the sunrise and sunset data sets. Because this is not the case

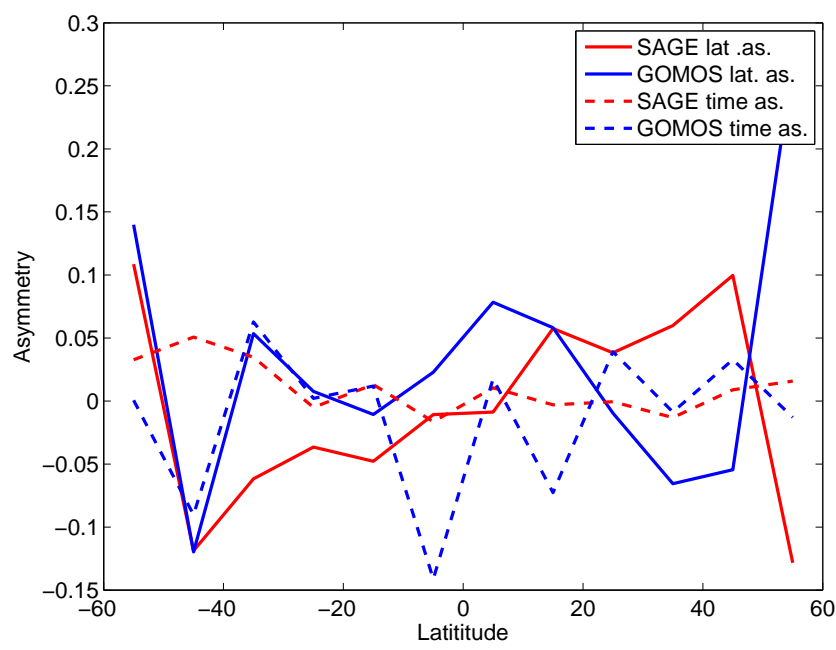

Fig. 6. The mean latitudinal and temporal asymmetries as a function of latitude.

(see Figs. 1 and 2), we continue with the separate sunrise and sunset data.

The decisive parameter that controls the relative bias between SAGE II and GOMOS is the local hour of the measurement. Therefore, we have three measurement sets: GOMOS nighttime, and sunset and sunrise from SAGE II. We have decided to keep the GOMOS data set as the reference and to shift the two SAGE II populations in such a way that they agree with the GOMOS data set in the common data period 2002-2005. As shown above, the bias profiles vary only slightly as a function of latitude or year, and we ignore these variations in this work. Here, we use the average, altitude dependent bias profiles from Fig. 3 for sunset and sunrise SAGE II measurements. Individual profiles are shifted using the appropriate bias profile. In this way, the corrected SAGE II profiles agree, on average, with the collocated GOMOS profiles for 2002-2005. We extend the same bias correction procedure to the SAGE II measurements from 1984 to 2001 before the common measurement period. The estimated uncertainty of the bias correction (small) is added to the error budget.

\subsection{The combined data set}

We have to decide what statistical estimators to use to characterize data in the grid cells exceeding $10^{\circ}$ in latitude and one month in time. We first construct individual instrument data series, and the averages in time-latitude cells are calculated by the median of the values (for error estimates of medians, see e.g. Kyrölä et al., 2010a). Outliers are removed by $|x-\operatorname{median}(x)|>3 \times 1.4826 \times \operatorname{median}(\mid x-\operatorname{median}(x)) \mid$. These individual instrument time series represent the combined data set for 1984-2001 and 2006-2011. For years 2002-2005, we have measurements from both instruments. For the combined data, we have decided to take the weighted 


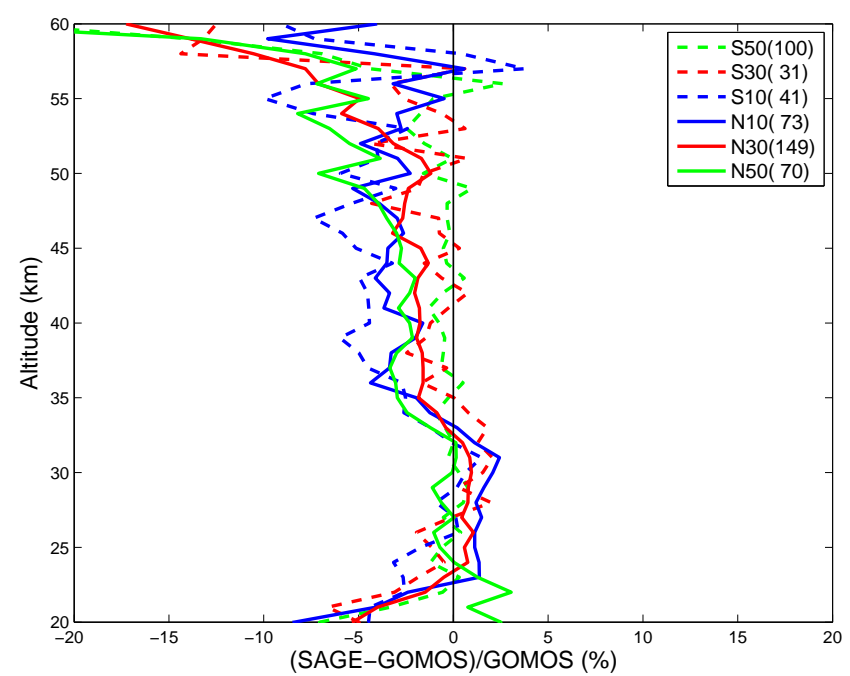

Fig. 7. The percent differences between SAGE II sunrise and GOMOS nighttime measurements in $20^{\circ}$ latitude bands. The line labels show the centers of the latitude bands and the number of collocations.

mean of the medians of the individual instrument data sets. The weights are the error estimates of the individual instrument medians. It is not obvious how to evaluate the error of the resulting weighted mean. If the difference between the instrument medians is larger than their error estimates predict, there is good reason to believe that the two instruments have not measured a homogeneous and stationary ozone field. To allow this kind of added uncertainty, we estimate the error using the dispersion correction for weighted mean error (see http://en.wikipedia.org/wiki/Weighted_mean). Figure 10 shows examples of the individual time series and the combined time series.

There are alternative ways to calculate a representative value in any grid cell. Instead of calculating averages (single instrument) with the median, the mean or a weighted mean could be used. The median is robust to outliers but, is deceptive to a double peak or similar structure in data distributions. A priori, in the common period 2002-2005 the weighted mean from all the measurements together could be an obvious choice. However, this approach is very sensitive to the consistent calculation of errors from both instruments. In large latitude-time cells the neutrality of the latitudinal and temporal sampling of measurements with respect to the natural variation can be an issue as discussed in Sect. 6.1. Weighting measurements may then lead to adverse effects.

\section{Time series analysis of SAGE II and GOMOS combined data set}

In order to assess the temporal evolution of ozone using the combined data sets, we carry out a time series analysis using

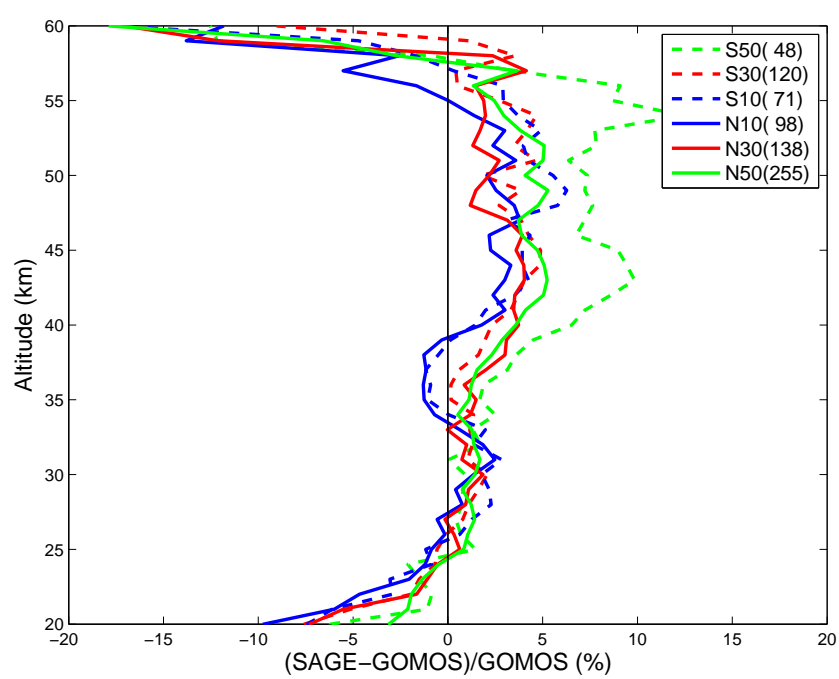

Fig. 8. The percent differences of SAGE II sunset and GOMOS nighttime measurements in $20^{\circ}$ latitude bands. The line labels show the centers of the latitude bands and the number of collocations.

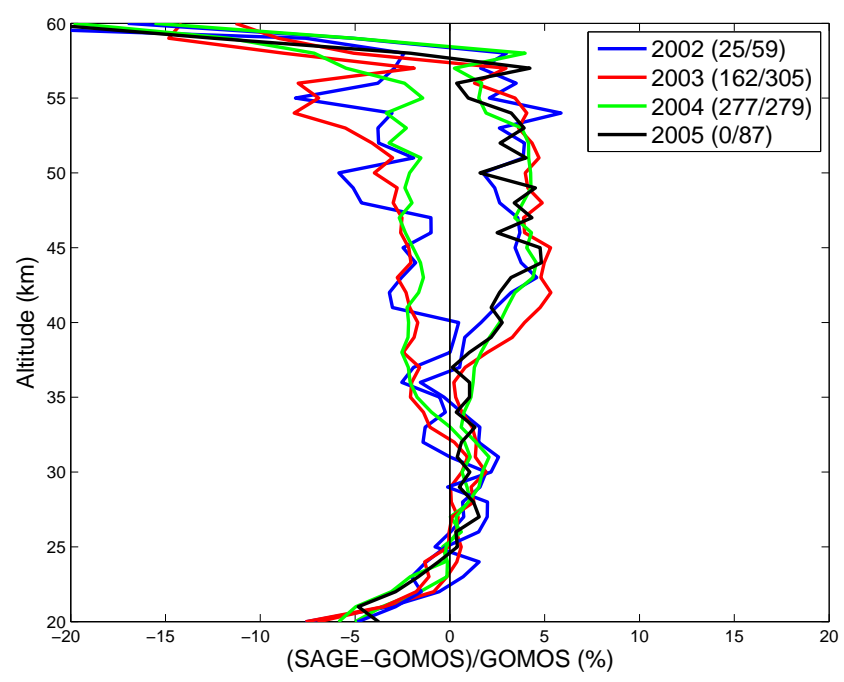

Fig. 9. The percent differences between SAGE II sunrise (mainly in left part of the figure) and sunset (mainly in right part of the figure) measurements and GOMOS nighttime ozone measurements as a function of measurement year. The line labels show the centers of the latitude bands and the number of collocations (sunrises/sunsets).

linear multi-variate regression. It is based on fitting the average profiles $\rho(z, t)(z=$ altitude, $t=$ time $)$ in each latitude bin with the following model:

$$
\begin{aligned}
& \rho^{\mathrm{fit}}(z, t)= \\
& c(z)+L(z, t)+s(z) F_{10.7}(t)+q_{1}(z) F_{\mathrm{qbo}}^{30}(t)+q_{2}(z) F_{\mathrm{qbo}}^{50}(t) \\
& +\sum_{n=1}^{2}\left(a_{n}(z) \cos (n w t)+b_{n}(z) \sin (n w t)\right)
\end{aligned}
$$




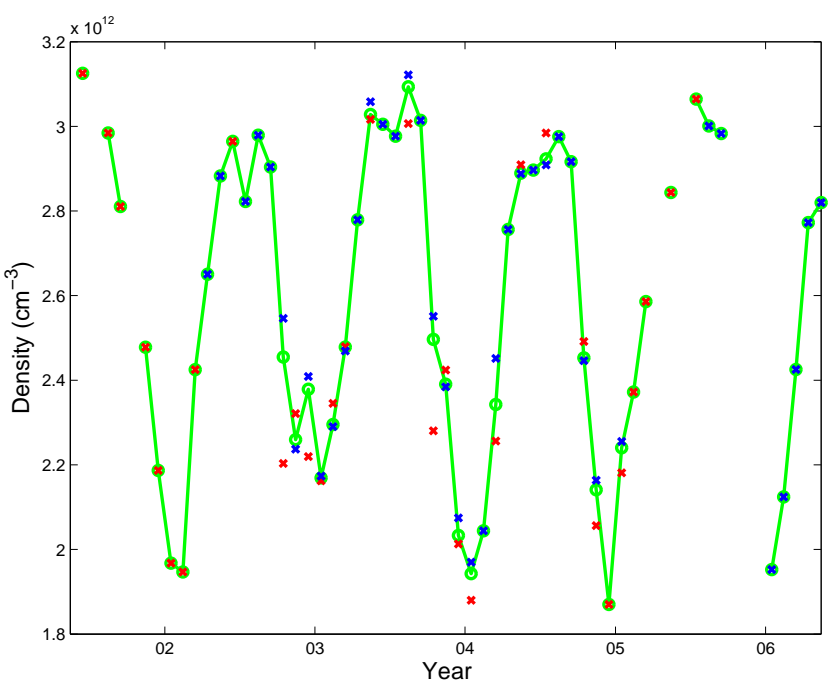

Fig. 10. An example of the combined SAGE II and GOMOS data sets at $30 \mathrm{~km}$ between $40-50^{\circ} \mathrm{N}$. Red crosses indicate SAGE II data, blues crosses indicate GOMOS data, and the green line with circles indicates the combined data (gaps in the line are due to missing data).

where $w=2 \pi / 365.25\left(1\right.$ day $\left.^{-1}\right)$. The first term is an altitude dependent constant. The second term, $L$, represents the linear time dependence. This can be a simple linear function of time, but we have selected it to be a piecewise linear function defined as

$L(z, t)=\left\{\begin{array}{l}d_{1}(z)\left(t-t_{\mathrm{c}}(z)\right) \text { if } t<t_{\mathrm{c}} \\ d_{2}(z)\left(t-t_{\mathrm{c}}(z)\right) \text { if } t \geq t_{\mathrm{c}} .\end{array}\right.$

This form of the linear dependence is often called the "hockey stick" form. It is parameterized by two slopes $d_{1}$, $d_{2}$ and the time of the inflection point $t_{\mathrm{c}}$. In Eq. (4) $F_{10.7}$, the solar $10.7 \mathrm{~cm}$ radio flux, is a proxy for solar influence on the middle atmosphere. $F_{\mathrm{qbo}}^{30}$ and $F_{\mathrm{qbo}}^{50}$ are the equatorial winds at $30 \mathrm{hPa}$ and at $50 \mathrm{hPa}$, respectively, and are proxies for the Quasi-Biennial Oscillations (QBO). The observational basis for these proxies is discussed in Harris et al. (1999) and WMO (2007) and references therein. The last terms represent harmonic variation up to the second order (with unknown amplitudes $a_{n}$ and $b_{n}$ ), i.e., annual and semiannual terms. The proxy terms are scaled in such a way that their time averages are zero, which makes it easier to compare their contributions with the harmonic and linear terms. The analysis is similar to the one in Kyrölä et al. (2010a).

The fitting of the model to the combined data determines the unknown coefficients $\left(c(z), s(z), q_{1}(z), q_{2}(z), a_{n}(z), b_{n}(z), d_{(}(z), d_{2}(z), t_{\mathrm{c}}(z)\right)$ in every latitude belt. The fitting is carried out as a classical least squares problem without data weighting. Autocorrelations are removed using the Cochrane-Orcutt transformation (see http://en.wikipedia.org/wiki/Cochrane-Orcutt_procedure). All latitudinal bands and altitudes are fitted separately with-

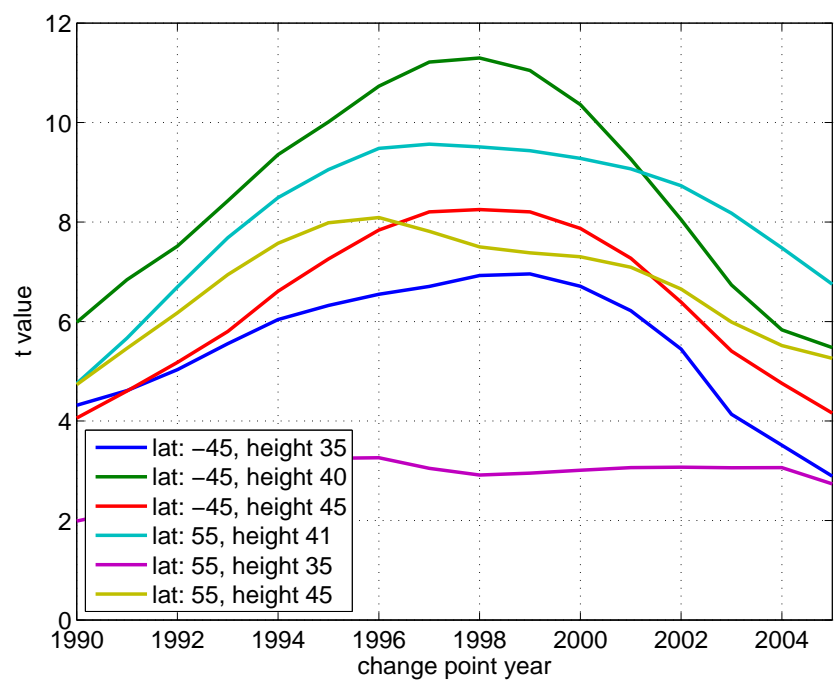

Fig. 11. The $t$ values for the difference of trend terms at different latitudes and altitudes as a function of the inflection year.

out any regularization terms. The estimated uncertainties are modified by the residual correction term. In the fitting process, we keep the inflection time outside the parameter optimization. The inflection time is determined by looking for the best overall fit result when varying the inflection year. The quality of the time series fit is analyzed by $t$ values (defined as a parameter value divided by its error estimate). Figure 11 shows how the $t$ values change as a function of the inflection year for mid-latitudes and for three altitudes. We can see that the inflection time is clearly 1997-1998 for measurements near $40 \mathrm{~km}$. For lower altitudes and lower latitudes our data do not support a clear turn around year. In our final analysis we accept the inflection year 1997 for all fits. Earlier, Newchurch et al. (2003) have obtained the same result using the cumulative sum (CUSUM) method to SAGE I/II and Halogen Occultation Experiment (HALOE) data. In Jones et al. (2009), several satellite data are used and the turn around time have been analyzed using $\chi^{2}$ values from the time series fit. This method is very similar to ours and the authors obtain a range of turn around years from 1994 to 1996 depending on altitude and latitude belt. In their trend analysis, however, they use a fixed year 1997 for all altitudes and latitudes. We study the determination of the turn around time more closely in the companion paper Laine et al. (2013).

In Fig. 12, we show an example of the fit in the latitude band $40-50^{\circ} \mathrm{N}$ at $40 \mathrm{~km}$. While the fitted curve follows most of the data points, there are still several points that fall outside the fit curve. One possible reason for these deviations is variation in temporal and/or latitudinal asymmetry, as discussed in connection with the choice of the common grid. Unfortunately, it is impossible to explain these "outliers" in the time series using asymmetries without turning to a priori 


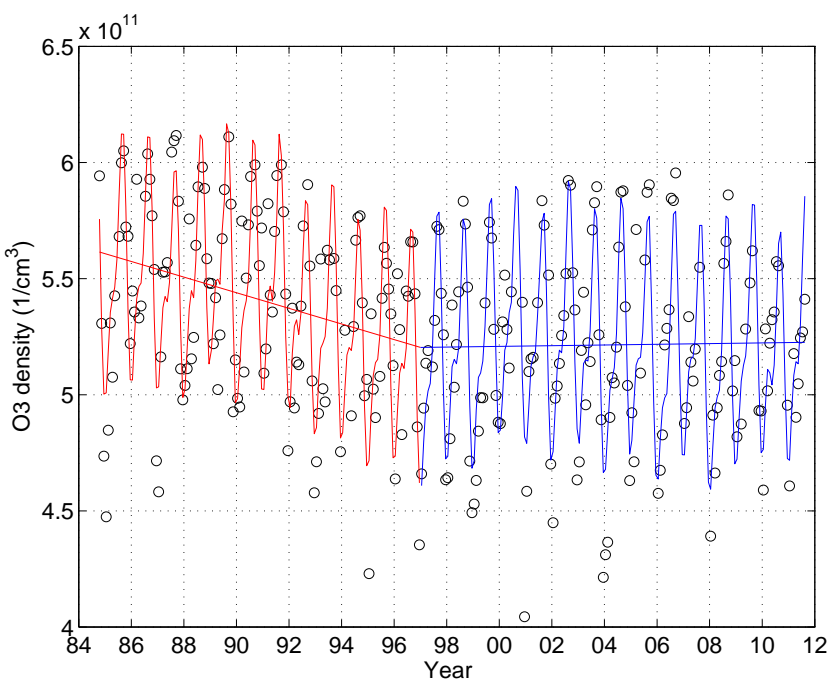

Fig. 12. An example of the fit at $40 \mathrm{~km}$ between $40-50^{\circ} \mathrm{N}$ for the combined SAGE II-GOMOS monthly data. The data points are black circles. The inflection year is 1997 . The red solid curve and red line line represent the fit and linear trend for 1984-1997, respectively. The blue solid curve and blue line represent the fit and linear trend for 1997-2011, respectively.

data on ozone variability. This question will be addressed in future publications.

As an example of the fitted proxy terms, we show, in Fig. 13, the solar term as percentage to the constant term of Eq. (4). The regions where solar term deviates from zero at $95 \%$ significance level are shaded. The statistically significant solar contribution is $1-3 \%$ in the stratosphere and 2$5 \%$ in the mesosphere. Note that the values are not totally symmetric around the Equator. These values are in agreement with the studies in Harris et al. (1999) and Randel and $\mathrm{Wu}(2007)$.

\section{Ozone trend}

The linear fitting coefficients in different latitude bands are shown as a function of altitude in Fig. 14 for 1984-1997 and in Fig. 15 for 1997-2011. Figure 16 shows the difference between these two trends. The regions where the results deviate from zero at the $95 \%$ significance level are shaded.

The trend results for 1984-1997 in Fig. 14 show clear negative trends in the altitude range of $20-60 \mathrm{~km}$ for all latitudes except the tropics between $25-35 \mathrm{~km}$ where we find a $1-3 \%$ positive trend (not statistically significant). In the altitude range $35-45 \mathrm{~km}$, the trends are $-8 \%$ per decade at mid-latitudes and $-4 \%$ in the tropics. In the altitude range $20-35 \mathrm{~km}$ the trend values are less negative, but the statistical uncertainty is large. In the mesosphere the trend varies between $-2 \%$ and $-4 \%$. These results can be compared with the results in Wang (2002). Figure 13 of this reference gives

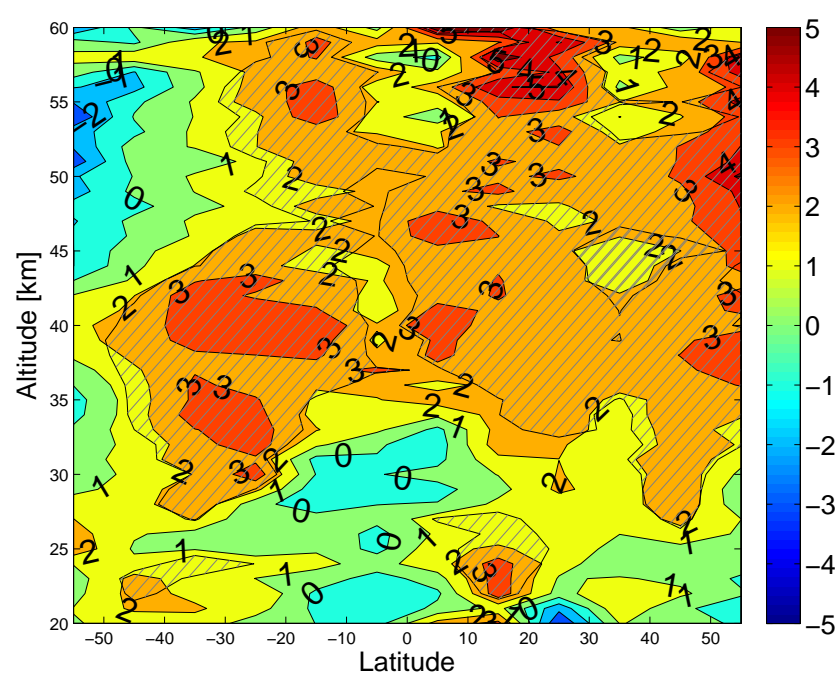

Fig. 13. The relative contribution of the solar proxy (\%) with respect to the constant term for 1984-2011. Shaded areas show regions where trends are statistically different from zero at the $95 \%$ level.

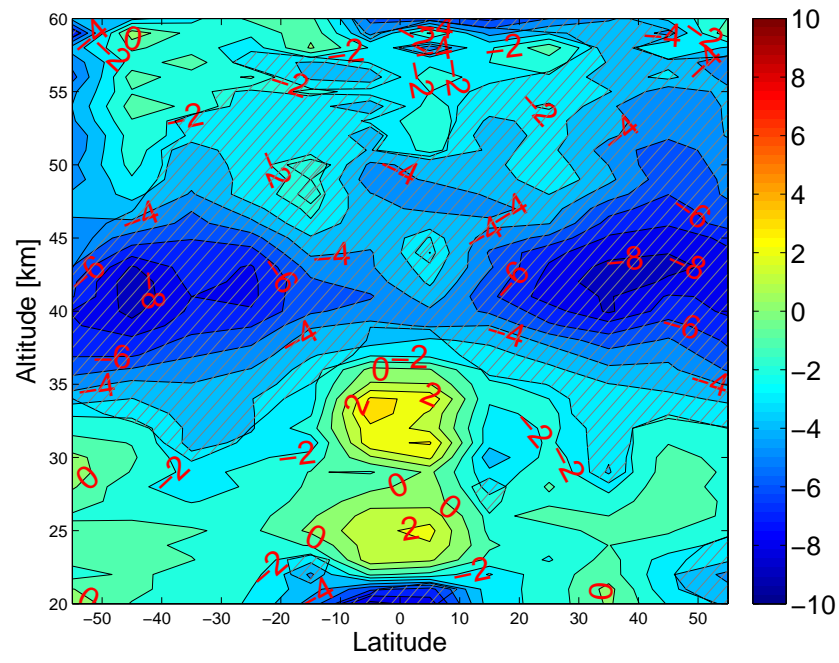

Fig. 14. The ozone trend in \% per decade for different latitudes for 1984-1997. Shaded areas show regions where trends are statistically different from zero at the $95 \%$ level.

the ozone trend from 1984-1999 based on SAGE II data version 6.1. At $40 \mathrm{~km}$, Wang (2002) reported $-3 \%$ per decade in the tropics and $-7 \%$ at mid-latitudes. At $20 \mathrm{~km}$ in the tropics, the rate is $-4 \%$. These values agree well with our results. The more recent study by Jones et al. (2009) uses data from several satellites covering the period from 1979 to 2008 (including SAGE II data with the version 6.2). Results are shown in wide latitudinal belts and in altitude ranges. In the period 1979-1997, the results show that between $35-45 \mathrm{~km}$ the trends are of $-7 \%$ per decade at mid-latitudes $\left(30-60^{\circ} \mathrm{N}\right.$ and $\left.30-60^{\circ} \mathrm{S}\right)$ and $-4 \%$ in the tropics $\left(30^{\circ} \mathrm{S}-30^{\circ} \mathrm{N}\right)$. If we 


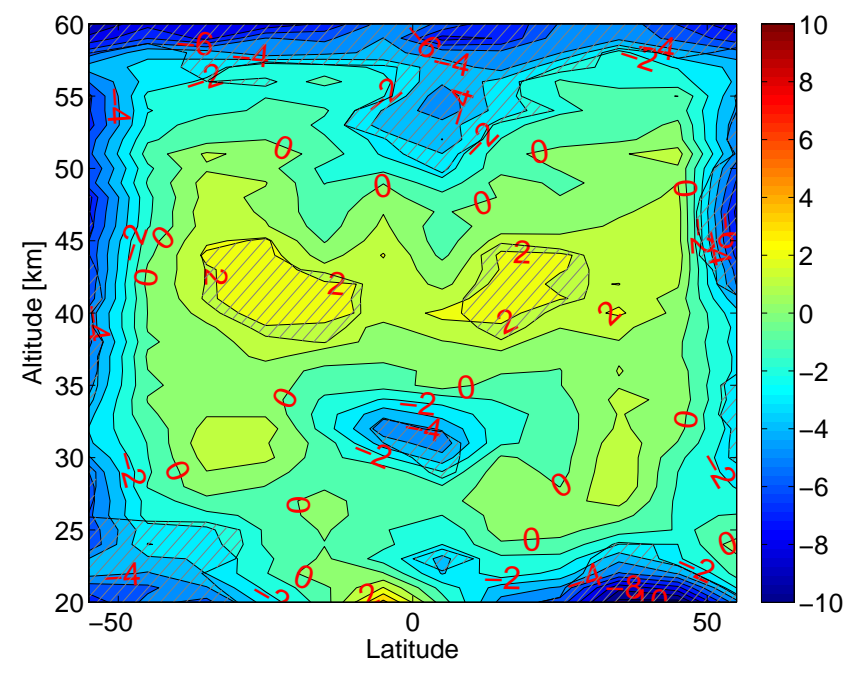

Fig. 15. The ozone trend in $\%$ per decade for different latitudes for 1997-2011. Shaded areas show regions where trends are statistically different from zero at the $95 \%$ level.

take averages of our results over the same altitudes and latitudes (without paying attention to the confidence regions) we get $-6 \%$ and $-4 \%$, respectively. Between $25-35 \mathrm{~km}$ Jones et al. (2009) found $-1.5 \%$ in southern mid-latitudes, $-3.3 \%$ in northern mid-latitudes, and $0.7 \%$ in the tropics. Our numbers are $-1.6 \%,-1.6 \%$, and $-0.7 \%$, respectively. Between 20-25 km Jones et al. (2009) found about $-4 \%$ at mid-latitudes and $+0.5 \%$ in the tropics whereas our values are $-0.9 \%$ in southern mid-latitudes, $-2 \%$ in in northern mid-latitudes and $-2.2 \%$ in the tropics.

The statistically significant trend (at $95 \%$ level) results for 1997-2011 in Fig. 15 show that mid-latitude and tropical ozone at $38-45 \mathrm{~km}$ is now increasing at a rate of $1-2 \%$ per decade. In the altitude range $30-35 \mathrm{~km}$ in the tropics, we find an interesting region where ozone has started to decrease (compare with Fig. 14, in which the trend in this region was positive) at a rate of $-2 \%$ to $-4 \%$ per decade (first discussed in Gebhardt et al., 2013). The latitudes outside $20^{\circ} \mathrm{S}-20^{\circ} \mathrm{N}$ in the lower stratosphere, $20-25 \mathrm{~km}$, show large ozone depletion rates of 2 to $10 \%$ per decade. In the mesosphere and in the stratosphere at high latitudes, the decrease of ozone is ongoing at a rate of $2-7 \%$ per decade. The only statistically significant trends for the period 1997-2008 in Jones et al. (2009) are between $25-35 \mathrm{~km}-2.1 \%$ in southern midlatitudes and $-2.7 \%$ in the tropics. The corresponding numbers in our data are $-1.7 \%$ and $-0.8 \%$, respectively.

In Fig. 16, we show how the trends in the period 19972011 have changed compared from those in the period 19841997. We find large, statistically significant (the $t$ value is now defined as $\left.t=\left(b_{2}-b_{1}\right) / \sqrt{(} s_{1}^{2}+s_{2}^{2}\right)$ where $b_{1}$ is the slope of the linear trend before 1997 with standard error of $s_{1}$ and $b_{2}$ and $s_{2}$ are the corresponding values for the slope after 1997) changes in trends at all latitudes in the $35-50 \mathrm{~km}$ al-

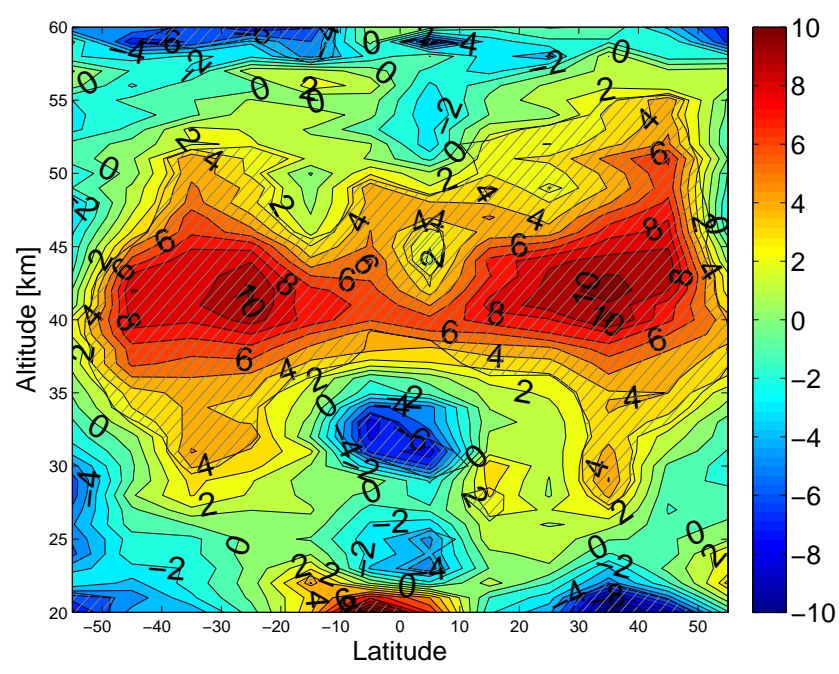

Fig. 16. The change in ozone trends in $\%$ per decade between the periods 1997-2011 and 1984-1997 at different latitudes. Shaded areas show regions where trend differences are statistically different from zero at the $95 \%$ level.

titude region. The largest changes towards the positive direction, 5-10\% per decade, have occurred at mid-latitudes. Between 28 and 35 in mid-latitudes the changes are smaller, 2-4\%. In the tropics between 23 and $35 \mathrm{~km}$, and at midlatitudes near $20 \mathrm{~km}$, the ozone loss has still increased. The rate changes in the mesosphere vary from negative to positive. Our change in trends between 1997-2011/1984-1997 can be compared with the change in trends between 19972008/1979-1997 calculated in Jones et al. (2009). They found that between $35-45 \mathrm{~km}$ the trends have moved towards the positive direction by $3.6 \%$ (in tropics) and by over $8 \%$ at mid-latitudes, whereas our numbers at all latitudes are around $5.4 \%$. Both data sets show, therefore, a clear change in trend. Between $25-35 \mathrm{~km}$, Jones et al. (2009) found worsening ozone loss $(-3.4 \%)$ in the tropics and recovery $(4.1 \%)$ in northern mid-latitudes, whereas our corresponding results are $-0.1 \%$ and $1.2 \%$, respectively. Between $20-25 \mathrm{~km}$ Jones et al. (2009) reported a strong positive change (3-4\%) in mid-latitudes, whereas we have a still worsening situation with approximately $-2-4 \%$ negative change of trends.

\section{Conclusions}

We have created a homogenized ozone profile data set from SAGE II and GOMOS measurements for the period 19842011 (Data are available from http://igaco-o3.fmi.fi/VDO/ index.html). A significant bias between SAGE II sunrise and sunset data with respect to GOMOS nighttime measurements has been identified. The most plausible reason for the bias is diurnal variation of ozone in the stratosphere. In combining individual instrument data, we have renormalized the SAGE II sunrise and sunset profiles so that they are unbiased with 
respect to GOMOS measurements in the common measurement period 2002-2005. The combined data set time series was then analyzed for trends in the stratosphere and mesosphere.

The combined SAGE II-GOMOS data set time series was analyzed using a linear regression model. This model includes a constant term, annual and semi-annual terms, solar and QBO proxies, and a linear term with two independent slopes joining at the inflection time. We found that year 1997 is the best estimate for the inflection year of linear trends. The trend results for 1984-1997 show clear negative trends (statistically significant at $95 \%$ level) for all latitudes outside the tropics in the altitude range of $30-60 \mathrm{~km}$. The trends for 1997-2011 are, however, slightly positive except in the mesosphere, in the stratosphere at high latitudes, and in the isolated tropical island between $30-35 \mathrm{~km}$. Due to the shortness of the time series, statistically significant results are still restricted in altitude and latitude. Comparing the trends during the period 1997-2011 with those during the period 19841997, we have a much better statistical significance. In the altitude region $35-50 \mathrm{~km}$ at all latitudes we find a clear large change towards ozone recovery. In mid-latitudes this positive change goes down to $28 \mathrm{~km}$, whereas in the tropics between 30 and $35 \mathrm{~km}$ ozone has surprisingly started to decrease after a small increase in the period 1984-1997.

It is thought that the estimated trends in this paper are real trends of the ozone distribution and not artifacts from instrumental drifts. Future studies will hopefully vindicate this statement. The time series model used to derive these trends is not complete enough to allow all of the data points to be fitted within error limits. A more flexible model will be introduced in the companion paper, Laine et al. (2013).

Acknowledgements. We want to thank the reviewers for their useful comments and corrections, which improved the manuscript. We want to thank R. Damadeo and N. Latva-Pukkila for their help in the preparation of the manuscript. We want to thank T. Sakazaki and the SMILES team for sharing their work before publication. We are grateful for the financial support from Academy of Finland (project numbers 134325 and 132808).

Edited by: M. Weber

\section{References}

Bertaux, J. L., Kyrölä, E., Fussen, D., Hauchecorne, A., Dalaudier, F., Sofieva, V., Tamminen, J., Vanhellemont, F., Fanton d'Andon, O., Barrot, G., Mangin, A., Blanot, L., Lebrun, J. C., Pérot, K., Fehr, T., Saavedra, L., Leppelmeier, G. W., and Fraisse, R.: Global ozone monitoring by occultation of stars: an overview of GOMOS measurements on ENVISAT, Atmos. Chem. Phys., 10, 12091-12148, doi:10.5194/acp-10-12091-2010, 2010.

Bogumil, K., Orphal, J., Homann, T., Voigt, S., Spietz, P., Fleischmann, O., Vogel, A., Hartmann, M., Kromminga, H., Bovensmann, H., Frerick, J., and Burrows, J.: Measurements of molec- ular absorption spectra with the SCIAMACHY pre-flight model: instrument characterization and reference data for atmospheric remote-sensing in the $230-2380 \mathrm{~nm}$ region, J. Photochem. Photobiol. A-Chemistry, 157, 167-184, doi:10.1016/S10106030(03)00062-5, 2003.

Burton, S. P., Thomason, L. W., and Zawodny, J. M.: Technical Note: Time-dependent limb-darkening calibration for solar occultation instruments, Atmos. Chem. Phys., 10, 1-8, doi:10.5194/acp-10-1-2010, 2010.

Chu, W. P., McCormick, M. P., Lenoble, J., Brogniez, C., and Pruvost, P.: SAGE II inversion algorithm, J. Geophys. Res., 94, 8339-8351, 1989.

Cunnold, D. M., Chu, W. P., McCormick, M. P., Veiga, R. E., and Barnes, R. A.: Validation of SAGE II ozone measurements, J. Geophys. Res., 94, 8447-8460, doi:10.1029/JD094iD06p08447, 1989.

Cunnold, D., Wang, H., Thomason, L., Zawodny, J., Logan, J., and Megretskaia, I.: SAGE (version 5.96) ozone trends in the lower stratosphere, J. Geophys. Res.-Atmos., 105, 4445-4457, 2000.

Damadeo, R. P., Zawodny, J. M., Thomason, L. W., and Iyer, N.: SAGE version 7.0 algorithm: application to SAGE II, Atmos. Meas. Tech. Discuss., 6, 5101-5171, doi:10.5194/amtd-6-51012013, 2013.

ESA: Envisat-GOMOS, An instrument for global atmospheric ozone monitoring, vol. SP-1244, European Space Agency, Noordwijk, the Netherlands, 2001.

Gebhardt, C., Rozanov, A., Hommel, R., Weber, M., Bovensmann, H., Burrows, J. P., Degenstein, D., Froidevaux, L., and Thompson, A. M.: Stratospheric ozone trends and variability as seen by SCIAMACHY during the last decade, Atmos. Chem. Phys. Discuss., 13, 11269-11313, doi:10.5194/acpd-13-11269-2013, 2013.

Harris, N., Hudson, R., and Phillips, C.: Assessment of trends in the vertical distribution of ozone, WMO, Geneva, 1999.

Hedin, A. E.: Extension of the MSIS thermospheric model into the middle and lower atmosphere, J. Geophys. Res., 96, 1159-1172, 1991.

Jones, A., Urban, J., Murtagh, D. P., Eriksson, P., Brohede, S., Haley, C., Degenstein, D., Bourassa, A., von Savigny, C., Sonkaew, T., Rozanov, A., Bovensmann, H., and Burrows, J.: Evolution of stratospheric ozone and water vapour time series studied with satellite measurements, Atmos. Chem. Phys., 9, 6055-6075, doi:10.5194/acp-9-6055-2009, 2009.

Kyrölä, E., Tamminen, J., Sofieva, V., Bertaux, J. L., Hauchecorne, A., Dalaudier, F., Fussen, D., Vanhellemont, F., Fanton d'Andon, O., Barrot, G., Guirlet, M., Fehr, T., and Saavedra de Miguel, L.: GOMOS $\mathrm{O}_{3}, \mathrm{NO}_{2}$, and $\mathrm{NO}_{3}$ observations in 2002-2008, Atmos. Chem. Phys., 10, 7723-7738, doi:10.5194/acp-10-77232010, 2010a.

Kyrölä, E., Tamminen, J., Sofieva, V., Bertaux, J. L., Hauchecorne, A., Dalaudier, F., Fussen, D., Vanhellemont, F., Fanton d'Andon, O., Barrot, G., Guirlet, M., Mangin, A., Blanot, L., Fehr, T., Saavedra de Miguel, L., and Fraisse, R.: Retrieval of atmospheric parameters from GOMOS data, Atmos. Chem. Phys., 10, 1188111903, doi:10.5194/acp-10-11881-2010, 2010 b.

Laine, M., Latva-Pukkila, N., and Kyrölä, E.: Analyzing time varying trends in stratospheric ozone time series using state space approach, Atmos. Chem. Phys. Discuss., 13, 20503-20530, doi:10.5194/acpd-13-20503-2013, 2013. 
McCormick, M., Zawodny, J., Veiga, R., Larsen, J., and Wang, P.: An overview of SAGE I and II ozone measurements, Planet. Space Sci., 37, 1567-1586, 1989.

McPeters, R. D., Miles, T., Flynn, L. E., Wellemeyer, C. G., and Zawodny, J. M.: Comparison of SBUV and SAGE II ozone profiles: Implications for ozone trends, J. Geophys. Res., 99, 2051320524, doi:10.1029/94JD02008, 1994.

Meijer, Y. J., Swart, D. P. J., Allaart, M., Andersen, S. B., Bodeker, G., Boyd, I., Braathen, G., Calisesi, Y., Claude, H., Dorokhov, V., von der Gathen, P., Gil, M., Godin-Beekmann, S., Goutail, F., Hansen, G., Karpetchko, A., Keckhut, P., Kelder, H. M., Koelemeijer, R., Kois, B., Koopman, R. M., Kopp, G., Lambert, J.C., Leblanc, T., McDermid, I. S., Pal, S., Schets, H., Stubi, R., Suortti, T., Visconti, G., and Yela, M.: Pole-to-pole validation of Envisat GOMOS ozone profiles using data from ground-based and balloon sonde measurements, JJ. Geophys. Res.-Atmos., 109, D23305, doi:10.1029/2004JD004834, 2004.

Nair, P. J., Godin-Beekmann, S., Pazmiño, A., Hauchecorne, A., Ancellet, G., Petropavlovskikh, I., Flynn, L. E., and Froidevaux, L.: Coherence of long-term stratospheric ozone vertical distribution time series used for the study of ozone recovery at a northern mid-latitude station, Atmos. Chem. Phys., 11, 4957-4975, doi:10.5194/acp-11-4957-2011, 2011.

Nair, P. J., Godin-Beekmann, S., Froidevaux, L., Flynn, L. E., Zawodny, J. M., Russell III, J. M., Pazmiño, A., Ancellet, G., Steinbrecht, W., Claude, H., Leblanc, T., McDermid, S., van Gijsel, J. A. E., Johnson, B., Thomas, A., Hubert, D., Lambert, J.-C., Nakane, H., and Swart, D. P. J.: Relative drifts and stability of satellite and ground-based stratospheric ozone profiles at NDACC lidar stations, Atmos. Meas. Tech., 5, 1301-1318, doi:10.5194/amt-5-1301-2012, 2012.

Newchurch, M. J., Yang, E.-S., Cunnold, D. M., Reinsel, G. C., Zawodny, J. M., and Russell, J. M.: Evidence for slowdown in stratospheric ozone loss: First stage of ozone recovery, J. Geophys. Res.-Atmos., 108, 4507, doi:10.1029/2003JD003471, 2003.

Randel, W. J. and Wu, F.: A stratospheric ozone profile data set for 1979-2005: Variability, trends, and comparisons with column ozone data, J. Geophys. Res.-Atmos., 112, D06313, doi:10.1029/2006JD007339, 2007.

Rienecker, M. M., Suarez, M. J., Gelaro, R., Todling, R., Bacmeister, J., Liu, E., Bosilovich, M. G., Schubert, S. D., Takacs, L., Kim, G.-K., Bloom, S., Chen, J., Collins, D., Conaty, A., da Silva, A., Gu, W., Joiner, J., Koster, R. D., Lucchesi, R., Molod, A., Owens, T., Pawson, S., Pegion, P., Redder, C. R., Reichle, R., Robertson, F. R., Ruddick, A. G., Sienkiewicz, M., and Woollen, J.: MERRA: NASA's Modern-Era Retrospective Analysis for Research and Applications, J. Climate, 24, 3624-3648, doi:10.1175/JCLI-D-11-00015.1, 2011.

Sakazaki, T., Fujiwara, M., Mitsuda, C., Imai, K., Manago, N., Naito, Y., Nakamura, T., Akiyoshi, H., Kinnison, D., Sano, T., Suzuki, M., and Shiotani, M.: Diurnal ozone variations in the stratosphere revealed in observations from the Superconducting Submillimeter-Wave Limb-Emission Sounder (SMILES) on board the International Space Station (ISS), J. Geophys. Res.Atmos., 118, 2991-3006, doi:10.1002/jgrd.50220, 2013.

Sofieva, V. F., Tamminen, J., Haario, H., Kyrölä, E., and Lehtinen, M.: Ozone profile smoothness as a priori information in the in- version of limb measurements, Ann. Geophys., 22, 3411-3420, doi:10.5194/angeo-22-3411-2004, 2004.

Sofieva, V. F., Vira, J., Kyrölä, E., Tamminen, J., Kan, V., Dalaudier, F., Hauchecorne, A., Bertaux, J.-L., Fussen, D., Vanhellemont, F., Barrot, G., and Fanton d'Andon, O.: Retrievals from GOMOS stellar occultation measurements using characterization of modeling errors, Atmos. Meas. Tech., 3, 1019-1027, doi:10.5194/amt-3-1019-2010, 2010.

Solomon, S.: Stratospheric ozone depletion: a review of concepts and history, Rev. Geophys., 37, 275-316, 1999.

Staehelin, J., Harris, N. R. P., and Appenzeller, C.: Ozone trends: A review, Rev. Geophys., 39, 231-290, 2001.

Steele, H. M. and Turco, R. P.: Separation of aerosol and gas components in the Halogen Occultation Experiment and the Stratospheric Aerosol and Gas Experiment (SAGE) II extinction measurements: Implications for SAGE II ozone concentrations and trends, J. Geophys. Res., 1021, 19665-19682, doi:10.1029/97JD01263, 1997.

Steinbrecht, W., Claude, H., Schönenborn, F., McDermid, I. S., Leblanc, T., Godin, S., Song, T., Swart, D. P. J., Meijer, Y. J., Bodeker, G. E., Connor, B. J., Kämpfer, N., Hocke, K., Calisesi, Y., Schneider, N., de la Noë, J., Parrish, A. D., Boyd, I. S., Brühl, C., Steil, B., Giorgetta, M. A., Manzini, E., Thomason, L. W., Zawodny, J. M., McCormick, M. P., Russell, J. M., Bhartia, P. K., Stolarski, R. S., and Hollandsworth-Frith, S. M.: Long-term evolution of upper stratospheric ozone at selected stations of the Network for the Detection of Stratospheric Change (NDSC), J. Geophys. Res.-Atmos., 111, D10308, doi:10.1029/2005JD006454, 2006.

Steinbrecht, W., Claude, H., Schonenborn, F., McDermid, I. S., Leblanc, T., Godin-Beekmann, S., Keckhut, P., Hauchecorne, A., van Gijsel, J. A. E., Swart, D. P. J., Bodeker, G. E., Parrish, A., Boyd, I. S., Kampfer, N., Hocke, K., Stolarski, R. S., Frith, S. M., Thomason, L. W., Remsberg, E. E., von Savigny, C., Rozanov, A., and Burrows, J. P.: Ozone and temperature trends in the upper stratosphere at five stations of the Network for the Detection of Atmospheric Composition Change, Int. J. Remote Sens., 30, 3875-3886, doi:10.1080/01431160902821841, 2009.

Tamminen, J., Kyrölä, E., Sofieva, V. F., Laine, M., Bertaux, J.-L., Hauchecorne, A., Dalaudier, F., Fussen, D., Vanhellemont, F., Fanton-d'Andon, O., Barrot, G., Mangin, A., Guirlet, M., Blanot, L., Fehr, T., Saavedra de Miguel, L., and Fraisse, R.: GOMOS data characterisation and error estimation, Atmos. Chem. Phys., 10, 9505-9519, doi:10.5194/acp-10-9505-2010, 2010.

van Gijsel, J. A. E., Swart, D. P. J., Baray, J.-L., Bencherif, H., Claude, H., Fehr, T., Godin-Beekmann, S., Hansen, G. H., Keckhut, P., Leblanc, T., McDermid, I. S., Meijer, Y. J., Nakane, H., Quel, E. J., Stebel, K., Steinbrecht, W., Strawbridge, K. B., Tatarov, B. I., and Wolfram, E. A.: GOMOS ozone profile validation using ground-based and balloon sonde measurements, Atmos. Chem. Phys., 10, 10473-10488, doi:10.5194/acp10-10473-2010, 2010.

Wang, H., Cunnold, D., and Bao, X.: A critical analysis of stratospheric aerosol and gas experiment ozone trends, J. Geophys. Res., 101, 12495-12514, 1996.

Wang, H. J.: Assessment of SAGE version 6.1 ozone data quality, J. Geophys. Res., 107, 1-18, doi:10.1029/2002JD002418, 2002.

Wang, P.-H., McCormick, M. P., Chu, W. P., Lenoble, J., Nagatani, R. M., Chanin, M. L., Barnes, R. A., Schmidlin, F., 
and Rowland, M.: SAGE II stratospheric density and temperature retrieval experiment, J. Geophys. Res., 97, 843-863, doi:10.1029/91JD02601, 1992.

Weatherhead, E. C., Reinsel, G. C., Tiao, G. C., Jackman, C. H., Bishop, L., Hollandsworth Firth, S. M., Deluisi, J., Keller, T., Oltmans, S. J., Fleming, E. L., Wuebbles, D. J., Kerr, J. B., Miller, A. J., Herman, J., and McPeters, R.: Detecting the recovery of total column ozone, J. Geophys. Res., 105, 22201-22210, 2000 .
WMO: Scientific Assessment of Ozone Depletion: 2006, Global Ozone Research and Monitoring Project - Report No. 50, World Meteorological Organization, Geneva, Switzerland, 2007.

WMO: Scientific Assessment of Ozone Depletion: 2010, Global Ozone Research and Monitoring Project - Report No. 52, World Meteorological Organization, Geneva, Switzerland, 2011. 